\title{
KONDISI RUMPUT LAUT ALAM DI PERAIRAN PANTAI UJUNG GENTENG, SUKABUMI DAN LABUHANBUA, SUMBAWA: POTENSI KARBON BIRU DAN PENGEMBANGAN BUDIDAYA
}

\author{
Erlania"\#, I Nyoman Radiarta"), Joni Haryadi"), dan Ofri Johan"' \\ ") Pusat Penelitian dan Pengembangan Perikanan Budidaya \\ Balai Penelitian dan Pengembangan Budidaya Ikan Hias
}

(Naskah diterima: 6 Maret 2015; Revisi final: 28 April 2015, Disetujui publikasi: 5 Juni 2015)

\begin{abstract}
ABSTRAK
Sumberdaya rumput laut alam yang berlimpah di perairan Indonesia merefleksikan besarnya potensi penyerapan karbon oleh rumput laut untuk mengurangi gas rumah kaca, $\mathrm{CO}_{2}$, yang merupakan salah satu faktor penyebab terjadinya fenomena perubahan iklim. Penelitian ini bertujuan untuk menganalisis potensi serapan karbon oleh rumput laut alam di kawasan pesisir Labuhanbua, Kabupaten Sumbawa, NTB dan Ujung Genteng, Kabupaten Sukabumi, Jawa Barat. Pengumpulan data lapangan berdasarkan titik-titik pengamatan yang disebar pada transek garis yang tegak lurus terhadap garis pantai; meliputi data luas tutupan, jenis, dan kandungan karbon rumput laut alam yang dominan ditemukan pada kedua lokasi penelitian. Hasil penelitian menunjukkan bahwa jenis-jenis rumput laut yang ditemukan di kawasan pantai Ujung Genteng terdiri atas 36 spesies dan di Labuhanbua 28 spesies. Berdasarkan besarnya simpanan karbon dalam bentuk biomassa pada berbagai spesies rumput laut alam di kedua lokasi penelitian, maka Sargassum sp., Padina sp., Dictyota dichotoma, Hydroclathrus clatratus, Gracilaria sp., G. foliifera, G. salicornia, Gelidium sp., dan Turbinaria sp., merupakan spesies potensial yang berperan sebagai media penyimpanan karbon biru, dan semua jenis tersebut dapat dikembangkan melalui aktivitas budidaya.
\end{abstract}

KATA KUNCI: karbon biru, rumput laut alam, simpanan karbon, mitigasi perubahan iklim, Sumbawa, Sukabumi

ABSTRACT: Condition of wild seaweeds ecosystem at Ujung Genteng Sukabumi and Labuhanbua, Sumbawa coastal waters: Potencies of blue carbon and mariculture development. By: Erlania, I Nyoman Radiarta, Joni Haryadi, and Ofri Johan

\begin{abstract}
Abundant wild seaweed resources in Indonesian waters reflect a great potencies of carbon sequestration by seaweeds on reducing green house gas, $\mathrm{CO}_{2}$, which become a causal factor of climate change. This study was conducted to analyze carbon sequestration potencies by wild seaweeds and possibility of seaweeds aquaculture development at coastal waters of Labuhanbua, Sumbawa, West Nusa Tenggara and Ujung Genteng, Sukabumi, West Java. Field data were collected base on observation stations which distributed along line-transects perpendicular to coast line; included coverage area, species, and carbon content of wild seaweeds which found on each observation stations at both sites. The results showed that 36 and 28 seaweed species were found at Ujung Genteng and Labuhanbua coastal waters, respectively. Based on stored carbon in biomass of wild seaweed species in both study sites, there were several potential species such as Sargassum sp., Padina sp., Dictyota dichotoma, Hydroclathrus clatratus, Gracilaria sp., G. foliifera, G. salicornia, Gelidium sp., and Turbinaria sp., which had function as blue carbon storage, and those could be developed by cultivation activity.
\end{abstract}

KEYWORDS: $\quad$ blue carbon, wild seaweeds, stored carbon, climate change mitigation, Sumbawa, Sukabumi

\section{PENDAHULUAN}

Rumput laut merupakan komoditas unggulan budidaya laut di Indonesia. Secara global, Indonesia

\# Korespondensi: Pusat Penelitian dan Pengembangan Perikanan Budidaya. Jl. Ragunan No. 20, Pasar Minggu, Jakarta Selatan 12540, Indonesia. Tel.: + (021) 7805051 E-mail: erlania_elleen@yahoo.com menduduki posisi kedua sebagai produsen rumput laut terbesar di dunia, setelah Cina, dengan kontribusi terhadap produksi global mencapai $20,6 \%$ pada tahun 2010 (FAO, 2012). Produksi rumput laut di Indonesia mengalami peningkatan yang sangat signifikan dari 1,7 juta ton tahun 2007 menjadi 3,9 juta ton tahun 2010 (KKP, 2011). Perairan Indonesia memiliki potensi rumput laut alam yang sangat besar. 
Habitat rumput laut alam biasanya tersebar luas di kawasan rataan terumbu (reef flat) yang berasosiasi dengan hamparan pasir, karang, pecahan karang, lamun ataupun pasir berlumpur, seperti yang ditemukan di Kepulauan Riau, Bangka-Belitung, Kepulauan Seribu, Karimunjawa, Selat Sunda, pantai Jawa bagian Selatan, Bali, Nusa Tenggara Barat, Nusa Tenggara Timur, pulau-pulau di Sulawesi dan Maluku (Kadi, 2004).

Rumput laut alam dapat berperan sebagai media penyerapan karbon biru (blue carbon). Beberapa penelitian telah memperlihatkan hasil tingkat serapan karbon oleh berbagai jenis rumput laut alam seperti di perairan pantai Jepang (Muraoka, 2004) dan India (Kaladharan et al., 2009). Besarnya sumberdaya rumput laut alam yang tersebar di perairan Indonesia merefleksikan besarnya potensi penyerapan karbon oleh rumput laut dalam mengurangi gas rumah kaca, $\mathrm{CO}_{2}$, yang menjadi salah satu faktor penyebab terjadinya fenomena pemanasan global dan perubahan iklim. Kawasan pesisir Labuhanbua, Kabupaten Sumbawa, NTB dan Ujung Genteng, Kabupaten Sukabumi, Jawa Barat memiliki potensi rumput laut alam yang cukup berlimpah. Di antara jenis rumput laut alam yang sudah dimanfaatkan dan diketahui nilai ekonomisnya oleh masyarakat adalah jenis Sargassum sp. Jenis ini umumnya dipanen oleh masyarakat sekitar pada musim-musim tertentu dan dijual kepada pengumpul lokal.

Eksploitasi yang dilakukan oleh masyarakat pesisir terhadap perairan pantai dan rumput laut alam secara terus-menerus dan kurang terkontrol, akan berdampak pada degradasi kondisi perairan dan penurunan ketersediaan rumput laut alam. Hal ini diperkirakan dapat terjadi karena belum terdapat regulasi yang mengatur tentang batasan-batasan dalam eksploitasi kawasan pesisir terutama untuk rumput laut alam, serta kurangnya kesadaran masyarakat tentang pelestarian lingkungan pesisir. Pengembangan budidaya rumput laut merupakan salah satu alternatif yang dapat dilakukan untuk mencegah terjadinya eksploitasi berlebih terhadap sumberdaya rumput laut alam. Aktivitas budidaya rumput laut di sekitar kawasan pesisir, selain berfungsi untuk meningkatkan perekonomian masyarakat pesisir, komoditas ini juga memiliki peran penting dalam penyerapan karbon (carbon sequestration) yang dapat menjadi salah satu alternatif dalam mitigasi perubahan iklim. Budidaya rumput laut dapat memberikan kontribusi yang relatif besar terhadap lingkungan melalui penyerapan karbon (Grimsditch \& Chung, 2012; Erlania et al., 2013a; Erlania \& Radiarta, 2014). Penelitian ini bertujuan untuk mengkaji potensi rumput laut alam di kawasan pesisir Labuhanbua, Kabupaten Sumbawa, NTB dan Ujung Genteng, Kabupaten Sukabumi, Jawa Barat dalam penyerapan karbon terkait peranannya dalam mitigasi perubahan iklim dan peluang pengembangannya melalui budidaya.

\section{BAHAN DAN METODE}

\section{Lokasi Penelitian dan Pengumpulan Data}

Penelitian telah dilaksanakan di Ujung Genteng, Kabupaten Sukabumi dan Labuhanbua, Kabupaten Sumbawa (Gambar 1). Kedua lokasi penelitian ini merefleksikan karakteristik pantai yang cukup berbeda, di mana kawasan pesisir Ujung Genteng mewakili pantai Selatan yang berhadapan langsung dengan Samudera Indonesia, sedangkan kawasan Labuhanbua merupakan kawasan pesisir yang cukup terlindung di Kabupaten Sumbawa. Lokasi penelitian yang disurvai berupa kawasan rataan terumbu (reefflat) dengan kedalaman perairan berkisar antara 0-3 m. Pengumpulan data lapangan di Labuhanbua dilakukan pada bulan September 2014 dan di Ujung Genteng pada bulan November 2014.

Sebaran titik pengamatan dirancang dengan sistem informasi geografis (SIG) berdasarkan line transect (transek garis) yang disebar tegak lurus terhadap garis pantai. Pada setiap transek garis terdapat titik-titik pengamatan dengan jumlah sesuai dengan lebar dari kawasan intertidal (Gambar 1). Jarak antar transek garis pada kedua lokasi disesuaikan dengan kondisi di lapangan. Di perairan Ujung Genteng 147 titik pengamatan disebar pada transek garis dengan jarak antar titik sekitar $50 \mathrm{~m}$, dan jarak antar transek garis yang berdekatan adalah sekitar $225 \mathrm{~m}$. Sedangkan di Labuhanbua 50 titik pengamatan disebar pada transek garis dengan jarak antar titik pengamatan sekitar $100 \mathrm{~m}$ dan jarak antar transek garis yang berdekatan adalah sekitar $250 \mathrm{~m}$.

Data yang dikumpulkan meliputi data jenis-jenis rumput laut alam, tutupan (coverage) dari setiap jenis rumput laut alam yang tersebar pada setiap titik pengamatan, serta luas area tutupan (coverage area) setiap jenis dari total luasan area yang disurvai di kedua lokasi penelitian. Setiap jenis rumput laut alam yang ditemukan di lapangan kemudian diambil sebagai contoh, untuk dilakukan identifikasi terhadap jenis-jenis yang ditemukan pada masing-masing lokasi. Identifkasi jenis rumput laut alam mengikuti Kalsum (2012) dan Soekendarsi et al. (2004). Dari semua jenis rumput laut yang ditemukan, beberapa contoh jenis rumput laut yang ditemukan dominan pada kedua lokasi penelitian, diambil dan dikeringkan untuk selanjutnya dilakukan analisis kandungan karbon organik total (total organic carbon/TOC) di laboratorium uji SEAMEO Biotrop, Bogor. Analisis kandungan TOC pada rumput laut alam dilakukan dengan metode Walkley-Black (Schumacher, 2002) dengan hasil dalam satuan \% bobot kering. 


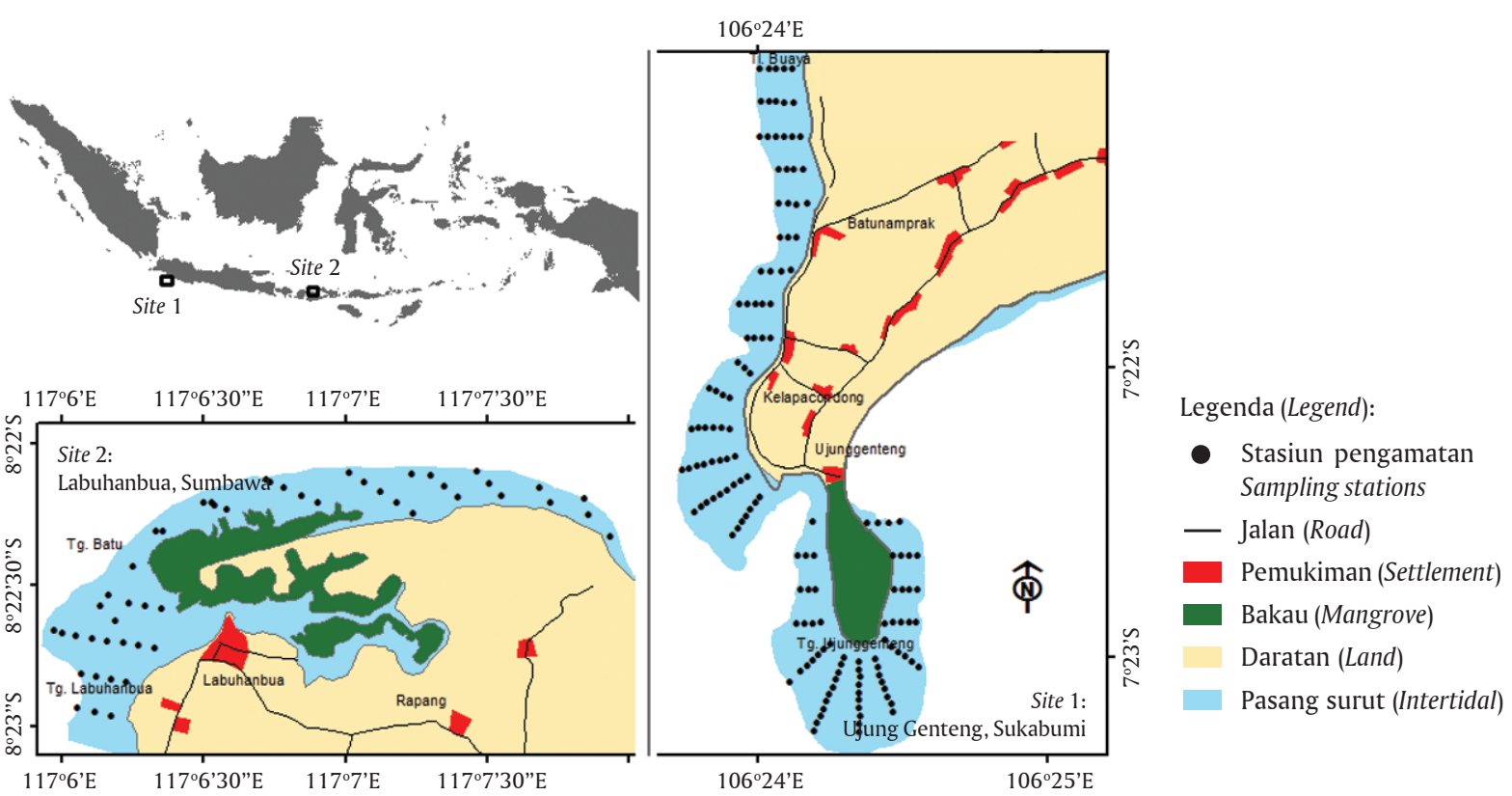

Gambar 1. Distribusi stasiun pengamatan rumput laut alam di perairan Ujung Genteng, Sukabumi, Jawa Barat dan Labuhanbua, Sumbawa, Nusa Tenggara Barat

Figure 1. Distribution of wild seaweed observation sites at Ujung Genteng, Sukabumi, West Java and Labuhanbua, Sumbawa, West Nusa Tenggara

\section{Analisis Data}

Stored carbon (simpanan karbon) pada rumput laut alam dikalkulasikan berdasarkan data kandungan karbon organik total dari setiap jenis rumput laut alam (\% bobot kering), tutupan rumput laut (\%), dan rata-rata biomassa rumput laut $\left(\mathrm{g} \mathrm{DW} / \mathrm{m}^{2}\right)$ (Mitra et al., 2014). Data rata-rata biomassa standar dari setiap kelompok rumput laut yang digunakan mengacu pada Dadolahi-Sohrab et al. (2012), yaitu biomassa ratarata Chlorophyta (alga hijau) sekitar 194,22 g DW $/ \mathrm{m}^{2}$; Phaeophyta (alga coklat) 908,80 g DW/ $\mathrm{m}^{2}$; dan Rhodophyta (alga merah) 649,67 g DW/ $\mathrm{m}^{2}$. Data yang terkumpul dianalisis secara spasial dan statistik, kemudian ditampilkan secara deskriptif dalam bentuk tabel dan gambar.

\section{HASIL DAN BAHASAN}

\section{Karakteristik Kawasan Pantai Ujung Genteng dan Labuanbua}

Perairan pantai Ujung Genteng, Kabupaten Sukabumi memiliki karakteristik yang relatif landai dan terlindung dari pecahan ombak. Perairan ini memiliki daerah intertidal yang luas dengan jarak hingga sekitar $150 \mathrm{~m}$ ke arah tengah, dan kedalaman maksimum sekitar $85 \mathrm{~cm}$ (Sukiman, 2011). Penggunaan lahan di wilayah pesisir Kabupaten Sukabumi, termasuk Desa Ujung Genteng cukup bervariasi, mulai dari daerah pertanian dan perkebunan, pelabuhan perikanan, kawasan wisata pantai, pemukiman, dan daerah konservasi, khususnya tempat bertelur penyu hijau, Chelonia mydas (Wahyudin, 2011). Ekosistem perairan pantai Ujung Genteng merupakan ekosistem yang relatif masih alami. Kawasan ini terdiri atas ekosistem yang bervariasi, antara lain hamparan padang lamun, terumbu karang, rumput laut, dan hutan mangrove; dengan substrat dasar pasir, lumpur, pecahan karang, dan batu karang. Ekosistem terumbu karang yang ditemukan di sekitar Ujung Genteng termasuk jenis karang tepi dengan kondisi yang umumnya sudah rusak dengan tutupan karang kurang dari 10\% (Wahyudin, 2011). Pada kawasan perairan ini tumbuh beragam spesies rumput laut yang tersebar pada hamparan area intertidal. Hasil penelitian Sukiman (2011) di perairan ini ditemukan sekitar 17 genus rumput laut yang terdiri atas 35 spesies. Berdasarkan hasil survai lapang yang dilakukan pada saat penelitian di kawasan pantai Ujung Genteng, ditemukan 26 genus dari tiga divisi yaitu: Chlorophyta, Rhodophyta, dan Phaepophyta; yang terdiri atas 39 spesies. Tutupan dari ketiga divisi rumput laut tersebut terdistribusi di sepanjang kawasan seperti pada Gambar 2. Keragaman dan distribusi jenis rumput laut yang ditemukan di antaranya dapat dipengaruhi oleh kondisi dasar perairan habitat yang berasosiasi di lingkungan tersebut. Semakin beragam tipe dan kompleksitas habitat maka keragaman jenis akan semakin tinggi (Smith, 1992).

Kabupaten Sumbawa memiliki sumberdaya kelautan dan perikanan yang cukup besar. Rumput laut merupakan salah satu komoditas budidaya unggulan dan prospektif yang terus dikembangkan di kabupa- 


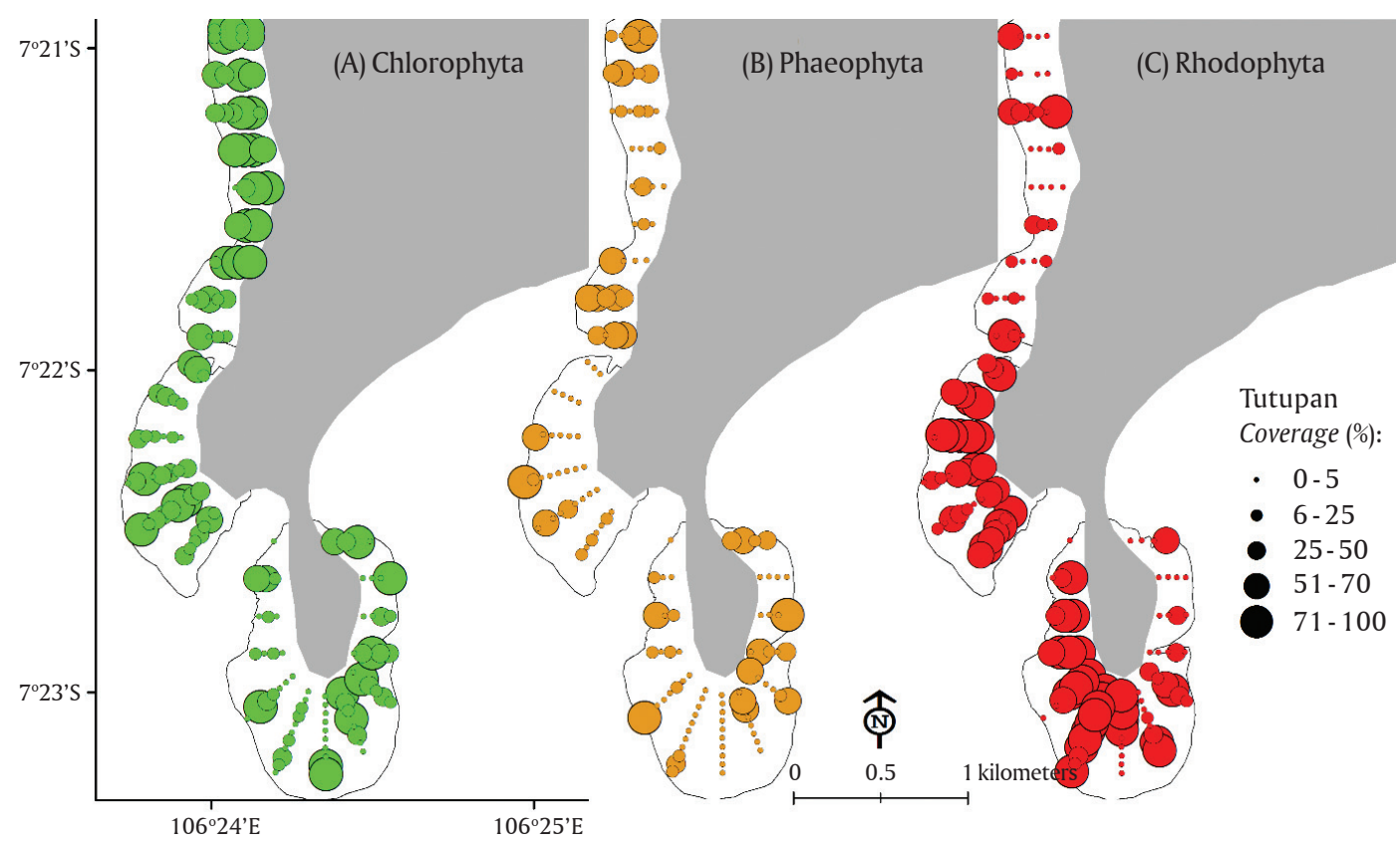

Gambar 2. Tutupan dan sebaran divisi rumput laut di kawasan rataan terumbu Ujung Genteng, Kabupaten Sukabumi, Jawa Barat

Figure 2. Coverage and distribution of seaweed divisions along reef flat area at Ujung Genteng, Sukabumi Regency, West Java

ten ini. Mengingat potensi lahan yang dimiliki cukup luas yaitu sekitar 14.950 ha, dan baru sekitar 40,50\% (5.650 ha) yang dimanfaatkan untuk budidaya rumput laut (Muhammading et al., 2011), menunjukkan bahwa masih terbuka luas kawasan untuk pengembangan dan peningkatan produksinya. Jenis rumput laut yang umumnya dibudidayakan di perairan Sumbawa adalah Kappaphycus alvarezii, dengan menggunakan metode rawai (long line). Program peningkatan produksi rumput laut ini telah sepenuhnya didukung baik oleh program nasional (minapolitan dan industrialisasi) maupun program pemerintah daerah (PIJAR: sapi, jagung, rumput laut). Selain rumput laut budidaya, ketersediaan rumput laut alam di kawasan pesisir Sumbawa sangat besar. Jenis rumput laut alam yang umumnya sudah dimanfaatkan oleh nelayan adalah Sargassum sp. Kawasan pesisir Labuhanbua, Kecamatan Utan merupakan salah satu lokasi yang memiliki potensi rumput laut alam yang cukup berlimpah. Rumput laut alam di lokasi ini tumbuh subur di kawasan rataan terumbu (reef flat) yang merupakan kawasan intertidal (pasang surut). Nelayan di kawasan ini umumnya melakukan pemanenan rumput laut jenis Sargassum sp. sekitar bulan Februari-Juni. Hasil pengamatan di lapangan menunjukkan bahwa potensi jenis rumput laut alam yang ada di rataan terumbu Labuhanbua, Sumbawa cukup bervariasi. Berdasarkan hasil survai lapang ditemukan 19 genus yang terdiri atas 43 spesies yang tersebar di sepanjang kawasan perairan Labuhanbua, Kabupaten Sumbawa (Gambar 3).

\section{Potensi Karbon Biru pada Rumput Laut Alam di Ujung Genteng, Sukabumi}

Isu pemanasan global akhir-akhir ini telah memicu ketertarikan yang sangat besar terhadap kemampuan vegetasi pantai dalam menangkap dan menyimpan karbon (carbon capture and storage/CCS) (Mitra et al., 2014). Saat ini, rumput laut merupakan salah satu komponen penting vegetasi pantai dalam konteks blue carbon (Elangbam et al., 2014; Mitra et al., 2014). Secara alami rumput laut dapat ditemukan menempel pada dasar perairan pantai yang relatif dangkal, hingga kedalaman $180 \mathrm{~m}$ pada substrat yang keras/ solid seperti: batu, karang, karang mati, kulit kerang, dan tumbuhan air lainnya (Alonso et al., 2012; Sahayaraj et al., 2014). Tumbuhan thallophyta ini, seperti halnya tumbuhan terestrial, dapat menyintesis makanannya sendiri melalui proses fotosintesis dengan bantuan cahaya matahari dan ketersediaan $\mathrm{CO}_{2}$ (karbon), serta nutrien di perairan. Beberapa hasil kajian menunjukkan bahwa rumput laut mempunyai peran penting dalam penyerapan karbon (Muraoka, 2004; Grimsditch \& Chung, 2012; Erlania et al., 2013a; Erlania \& Radiarta, 2014). Namun, jika dibandingkan dengan jenis vegetasi lainnya, potensi serapan karbon oleh rumput laut alam masih belum banyak diketahui (Mitra et al., 2014).

Berdasarkan hasil analisis beberapa spesies rumput laut alam yang ditemukan di perairan Ujung Genteng, Sukabumi; telah diketahui data kandungan karbon (C total) dari masing-masing spesies tersebut 

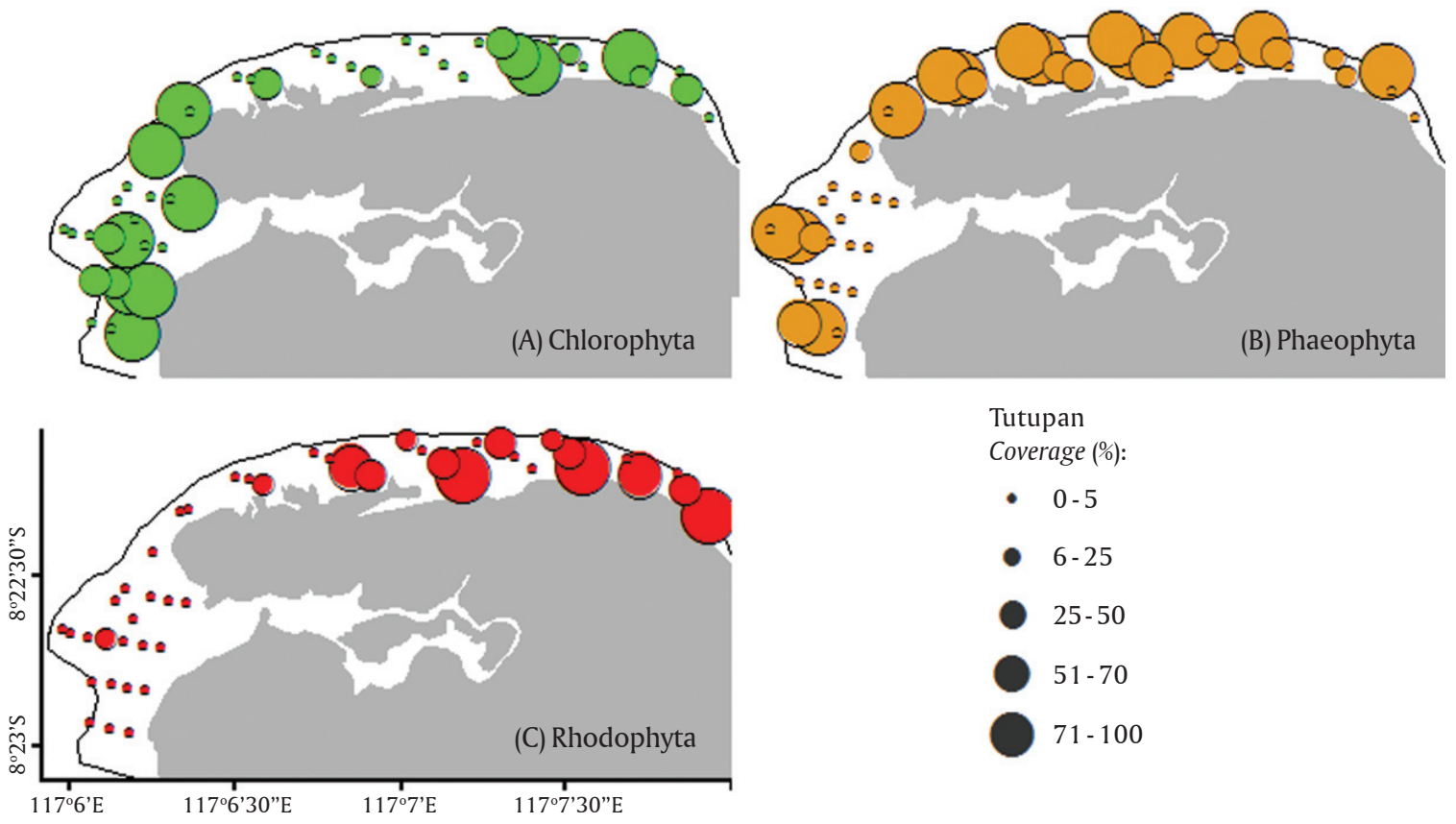

Tutupan

Coverage (\%):

- $0-5$

- 6-25

25-50

$51-70$

$71-100$

Gambar 3. Tutupan dan sebaran divisi rumput laut di kawasan rataan terumbu di kawasan rataan terumbu Labuhanbua, Kabupaten Sumbawa, Nusa Tenggara Barat

Figure 3. Coverage and distribution of seaweed divisions along reef flat area at Labuhanbua, Sumbawa Regency, West Nusa Tenggara

Dari tiga kelompok besar rumput laut (Chlorophyta, Phaeophyta, dan Rhodophyta), diperoleh nilai kandungan $C$ berkisar antara 3,06\%-33,32\%. Pada kelompok Chlorophyta, spesies rumput laut yang memiliki kandungan C tertinggi adalah Ulva fasciata yaitu sebesar 32,75\%. Turbinaria sp. merupakan spesies dengan kandungan karbon tertinggi dari kelompok Phaeophyta yaitu sekitar $31,14 \%$; sedangkan dari kelompok Rhodophyta yang memiliki kandungan $\mathrm{C}$ tertinggi adalah Galaxaura rugosa, yaitu 33,32\% (Tabel 1).

Berdasarkan kandungan karbon dari beberapa spesies rumput laut alam yang ditemukan di kawasan pantai Ujung Genteng diperoleh nilai simpanan karbon dari masing-masing spesies rumput laut yang bervariasi, yaitu antara 5,94-283,00 g C/m² (Gambar 4). Penelitian Mitra et al. (2014) terkait simpanan karbon pada beberapa spesies rumput laut alam di perairan pantai India menunjukkan hasil yang bervariasi, yaitu 46,41-152,43 g C/m² (U. lactuca); 13,70-51,44 $\mathrm{g} \mathrm{C} / \mathrm{m}^{2}$ (Catenella repens); dan 1.022,18-1.067,02 g C/ $\mathrm{m}^{2}$ (Enteromorpha intestinalis). Penelitian yang sama oleh Muraoka (2004) di perairan pantai Jepang juga menunjukkan nilai simpanan karbon yang bervariasi antar spesies rumput laut alam. Variasi serapan dan simpanan karbon pada rumput laut di alam lebih bersifat species-specific; di antaranya dipengaruhi oleh struktur morfologi dan jenis maupun jumlah pigmen yang terkandung pada masing-masing spesies rumput laut itu sendiri (Erlania et al., 2013a; Mitra et al., 2014).
Di antara ketiga kelompok makroalga tersebut terdapat beberapa spesies yang memiliki kemampuan tertinggi dalam menangkap dan menyimpan karbon dalam biomassa; yaitu Turbinaria sp., Sargassum sp., dan Galaxaura rugosa. Nilai simpanan karbon oleh ketiga spesies rumput laut ini berturut-turut adalah 283,00g C/m²; 275,20 g C/m²; dan 216,47 g C/m² (Gambar 4). Turbinaria sp. dan Sargassum sp. termasuk kelompok alga coklat. Kedua spesies ini sangat banyak ditemukan di area dekat tubir pantai di mana pada area tersebut merupakan titik pecahnya gelombang yang pada saat surut terendah masih terendam air. Kedua spesies ini memiliki tekstur yang keras dan tumbuh menempel kuat pada substrat batu karang, sehingga aman dari pengaruh gelombang dan hempasan ombak.

Secara umum, kelompok Phaeophyta memiliki simpanan karbon yang lebih tinggi, kemudian diikuti oleh kelompok Rhodophyta dan Chlorophyta (Gambar 4). Hal ini disebabkan karena spesies dari Phaeophyta maupun Rhodophyta memiliki pigmen tambahan berupa phycobilins (phycoerythrin, phycocyanin) dan/atau carotenoids yang berperan dalam membantu penyerapan energi cahaya yang dibutuhkan pada proses fotosintesis; pigmen ini dapat menyerap cahaya pada panjang gelombang yang sedikit berbeda dengan klorofil (Dawes, 1981). Pigmen tambahan ini sangat berperan pada saat kondisi rumput laut berada pada kondisi air yang dalam dan intensitas cahaya yang masuk relatif rendah, sehing- 
Tabel 1. Potensi simpanan karbon dari beberapa jenis rumput laut alam di kawasan rataan terumbu Ujung Genteng, Kabupaten Sukabumi, Jawa Barat

Table 1. Stored carbon potencies from several wild seaweed species along reef flat area at Ujung Genteng, Sukabumi Regency, West Java

\begin{tabular}{ccccc}
\hline $\begin{array}{c}\text { Kelompok } \\
\text { rumput laut } \\
\text { Seaweed group }\end{array}$ & $\begin{array}{c}\text { Jenis rumput laut } \\
\text { Seaweed species }\end{array}$ & $\begin{array}{c}\text { Kandungan C } \\
\text { C content } \\
\text { (\% DW) }\end{array}$ & $\begin{array}{c}\text { Tutupan } \\
\text { Coverage } \\
\text { (\%) }\end{array}$ & $\begin{array}{c}\text { Area tutupan } \\
\text { Coverage area } \\
\text { (ha) }\end{array}$ \\
\hline Halimeda micronesica & 3.06 & 1.03 & 2.09 \\
Chlorophyta & Chaetomorpha crassa & 22.15 & 3.12 & 6.33 \\
Green algae & Ulva reticulata & 26.38 & 12.38 & 25.13 \\
& Ulva fasciata & 32.75 & 0.38 & 0.77 \\
& Valoniopsis pachynema & 27.01 & 0.08 & 0.16 \\
\hline Phaeophyta & Padina sp. & 8.28 & 5.60 & 11.37 \\
Brown algae & Turbinaria sp. & 31.14 & 5.36 & 10.88 \\
& Dictyota bartayresiana & 22.07 & 0.90 & 1.83 \\
& Sargassum sp. & 30.282 & 3.76 & 7.63 \\
\hline & Jania adherens & 3.56 & 5.08 & 10.31 \\
Rhodophyta & Red turf alga & 14.92 & 1.02 & 2.07 \\
Red algae & Gracilaria foliifera & 19.04 & 14.55 & 29.54 \\
& Hypnea asperi Bory & 32.70 & 2.29 & 4.65 \\
& Gracilaria salicornia & 27.56 & 4.95 & 10.05 \\
& Galaxaura rugosa & 33.32 & 0.15 & 0.30 \\
& Actinotrich hia fragilis & 4.21 & 0.08 & 0.16 \\
\hline
\end{tabular}

ga hanya spektrum cahaya dengan panjang gelombang tertentu yang dapat mencapai dasar perairan.

Berdasarkan luasan area tutupan rumput laut dan luas kawasan perairan Ujung Genteng yang disurvai pada saat penelitian, yaitu sekitar 203 ha, dapat diestimasi kontribusi simpanan karbon dari setiap spesies pada suatu kawasan seperti pada Gambar 5. Dari setiap kelompok rumput laut ini terdapat spesies yang mendominasi ekosistem pantai tersebut, sehingga kombinasi nilai simpanan karbon dengan luas tutupan habitat memberikan kontribusi yang bervariasi dari setiap spesies. Dari kelompok Chlorophyta, simpanan karbon Ulva reticulata relatif hampir sama dengan beberapa spesies Chlorophyta lainnya (Gambar 4), namun karena memiliki luas tutupan yang relatif tinggi sehingga diestimasi dapat memberikan kontribusi tertinggi dalam menyimpan karbon di antara spesies Chlorophyta lainnya pada kawasan tersebut; yaitu: 12,88 ton C/ha (Gambar 5, Tabel 1). Pada kelompok Phaeophyta, Turbinaria sp. dan Sargassum sp. memiliki kandungan karbon 31,14\% dan 30,28\% dengan nilai simpanan karbon tertinggi, serta luas tutupan yang juga relatif tinggi (Tabel 1, Gambar 4); sehingga kedua spesies ini memberikan kontribusi tertinggi dalam penyimpanan karbon di antara spesies Phaeophyta lainnya; yaitu: 30, 80 dan 21,01 ton C/ha (Gambar 5). Pada kelompok Rhodo- phyta, walaupun Galaxaura rugosa dan Hypnea asperi Bory memiliki nilai simpanan karbon tertinggi, namun kontribusi tingkat simpanan karbon tertinggi pada kawasan tersebut berasal dari dua spesies lainnya yang memiliki luas tutupan mencapai $29,54 \%$ dan 10,05\% dari total 203 ha luasan area yang disurvai (Gambar 4, Tabel 1). Kedua spesies tersebut adalah G. foliifera dan G. salicornia yang memberikan kontribusi cukup besar dalam penyimpanan karbon dari kawasan perairan Ujung Genteng, yaitu berturutturut 36,54 dan 17,99 ton C/ha (Gambar 5, Tabel 1).

Berdasarkan kombinasi antara kemampuan serapan karbon dan besarnya biomassa yang dapat diproduksi oleh berbagai spesies rumput laut alam di kawasan perairan Ujung Genteng, Sukabumi; maka G. foliifera, Turbinaria sp., Sargassum sp., dan G. salicornia merupakan spesies potensial yang dapat dikembangkan melalui proses budidaya. Keempat spesies ini dapat menghasilkan produksi biomassa yang tinggi sekaligus dapat berkontribusi dalam mitigasi perubahan iklim melalui tingkat simpanan karbon yang tinggi.

\section{Potensi Karbon Biru pada Rumput Laut Alam di Labuhanbua, Sumbawa}

Analisis kandungan karbon dari beberapa spesies yang dominan ditemukan di perairan Labuhanbua, 


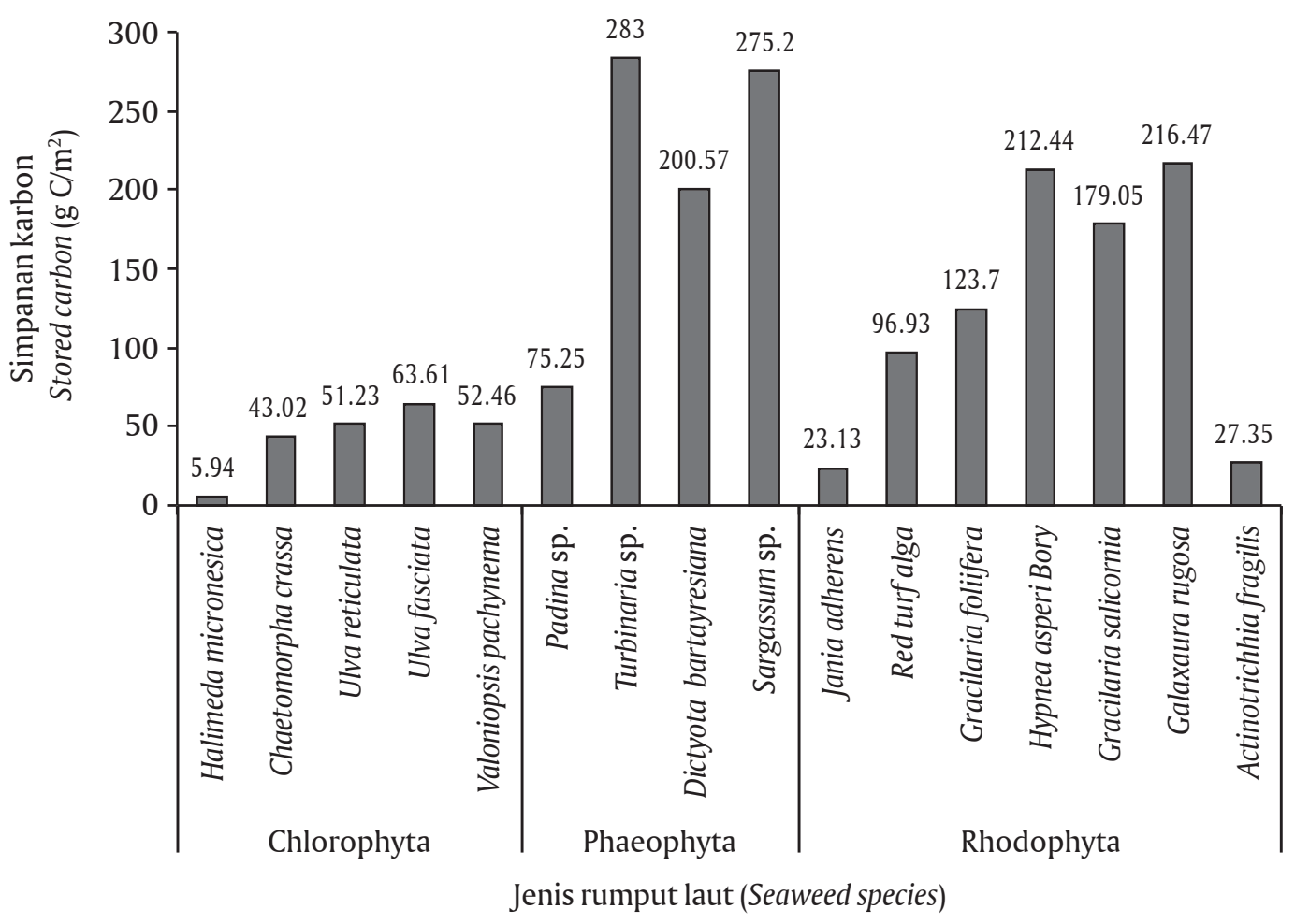

Gambar 4. Variasi simpanan karbon beberapa jenis rumput laut alam di kawasan rataan terumbu Ujung Genteng, Kabupaten Sukabumi, Jawa Barat

Figure 4. Variability of stored carbon from several wild seaweed species along reef flat area at Ujung Genteng, Sukabumi Regency, West Java

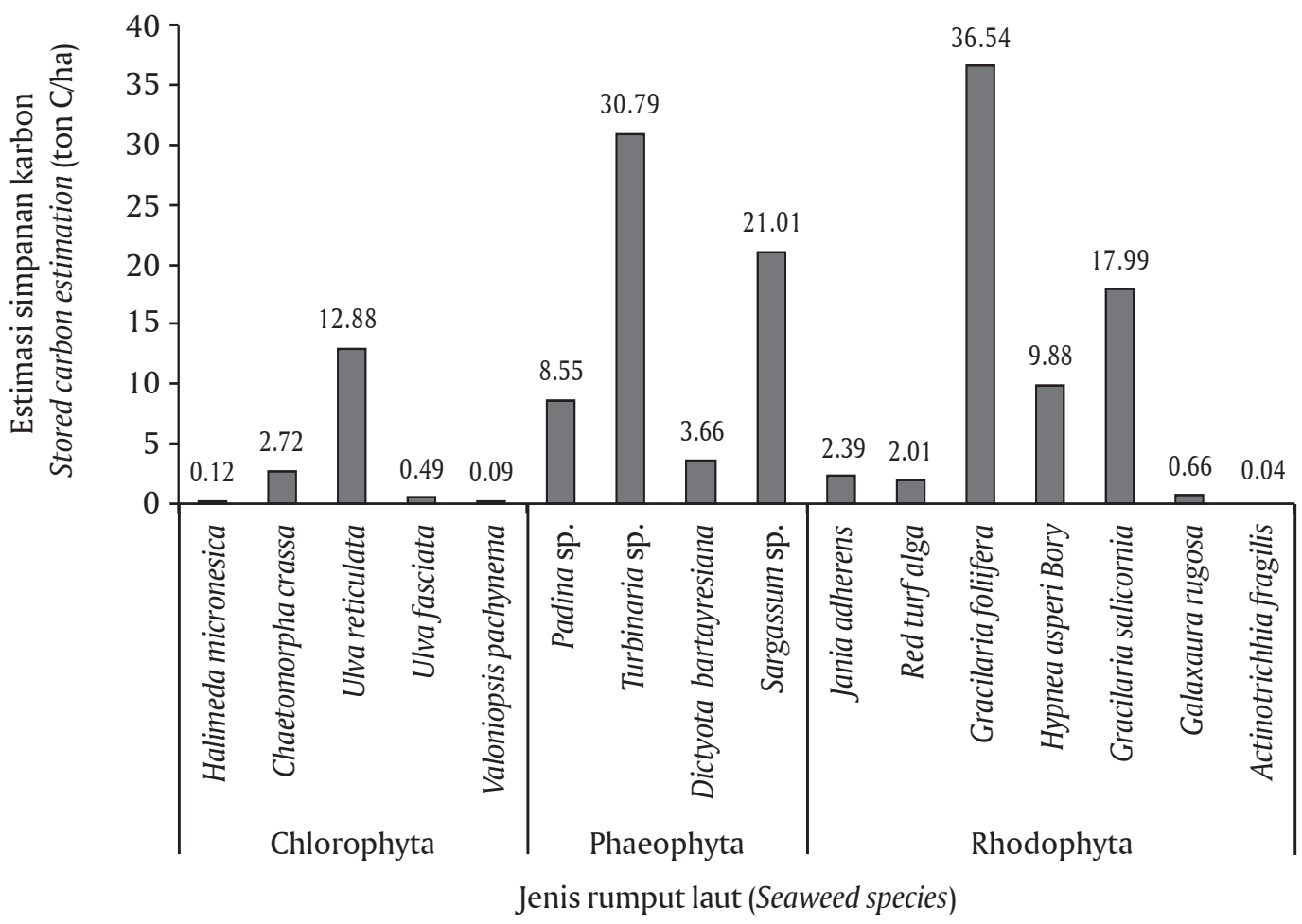

Gambar 5. Estimasi simpanan karbon oleh beberapa jenis rumput laut alam berdasarkan luas tutupan di kawasan rataan terumbu Ujung Genteng, Kabupaten Sukabumi, Jawa Barat

Figure 5. Stored carbon estimation by several wild seaweed species based on its coverage along reef flat area at Ujung Genteng, Sukabumi Regency, West Java 
Kabupaten Sumbawa menunjukkan hasil yang cukup bervariasi di antara ketiga kelompok rumput laut, yaitu berkisar antara 4,53\%-25,66\% (Tabel 2). Pada kelompok Chlorophyta ditemukan kandungan karbon tertinggi pada jenis Caulerpa sp. yaitu 25,66\%; sedangkan pada kelompok Phaeophyta dan Rhodophyta, kandungan karbon tertinggi ditemukan pada jenis Turbinaria sp. $(22,04 \%)$ dan Gracilaria salicornia $(23,00 \%)$. Variabilitas kandungan karbon pada rumput laut alam ini dipengaruhi oleh berbagai faktor di antaranya jenis rumput laut, iklim/musim dan karakteristik kawasan pesisir tempat tumbuhnya rumput laut (Mitra et al., 2014).

Variabilitas simpanan karbon pada masing-masing spesies dari tiga kelompok rumput laut alam yang ditemukan di perairan Labuhanbua ini berkisar antara 8,80-200,30 g C/m² (Gambar 6). Kisaran nilai tersebut relatif hampir sama dengan rumput laut yang ditemukan di perairan Ujung Genteng (Gambar 4). Dari tiga kelompok rumput laut tersebut, terdapat beberapa spesies rumput laut yang memiliki nilai simpanan karbon tertinggi, yaitu: Turbinaria sp., Dictyota ichotoma, G. salicornia, dan Sargassum sp. (Gambar 6). Dua spesies yaitu Turbinaria sp. dan Sargassum sp. ini juga termasuk spesies yang memiliki nilai simpanan karbon tertinggi yang ditemukan di perairan Ujung Genteng, Sukabumi (Gambar 4). Salah satu faktor yang memengaruhi terhadap kapasitas simpanan karbon ini adalah kondisi iklim/musim. Hasil studi yang dilakukan oleh Mitra et al. (2014) tentang simpanan karbon pada rumput laut alam di perairan India menunjukkan bahwa adanya variasi kandungan karbon pada Enteromorpha intestinalis pada musim yang berbeda. Pada saat moonson kandungan karbon pada Enteromorpha intestinalis mencapai $46,41 \mathrm{~g} \mathrm{C} / \mathrm{m}^{2}$; sedangkan saat pre-moonson mengalami kenaikan hingga mencapai $152,43 \mathrm{~g} \mathrm{C} / \mathrm{m}^{2}$.

Berdasarkan luasan area yang disurvai di kawasan Labuhanbua, yaitu sekitar 173 ha dan luas tutupan area dari masing-masing spesies rumput laut, maka estimasi simpanan karbon oleh masing-masing spesies rumput laut di kawasan tersebut diperoleh seperti pada Gambar 7. Perbedaan luas tutupan menghasilkan kontribusi tingkat simpanan karbon yang bervariasi dari setiap spesies pada suatu kawasan. Pada kelompok Chlorophyta, Caulerpa sp. memiliki nilai simpanan karbon yang tertinggi (Gambar 6). Namun, jenis Halimeda sp. diestimasi memberikan kontribusi simpanan karbon tertinggi di antara spesies Chlorophyta di kawasan perairan tersebut, yaitu 3,17 ton C/ha (Gambar 7); karena jenis ini memiliki luas tutupan yang lebih tinggi. Pada kelompok Phaeophyta, Padina sp. memiliki kontribusi tertinggi dalam menyimpan karbon yaitu 52,79 ton C/ha; sedangkan dari kelompok Rhodophyta kontribusi simpanan karbon tertinggi di kawasan perairan tersebut berasal dari G. salicornia, yaitu 23,14 ton C/ha (Gambar 7). Berdasarkan kapasitas simpanan karbon masing-masing spesies dari ketiga kelompok rumput laut, mengindikasikan bahwa Padina sp., Dictyota

Tabel 2. Potensi simpanan karbon dari beberapa jenis rumput laut alam di kawasan rataan terumbu Labuhanbua, Kabupaten Sumbawa, Nusa Tenggara Barat

Table 2. Stored carbon potencies from several wild seaweed species along reef flat area at Labuhanbua, Sumbawa Regency, West Nusa Tenggara

\begin{tabular}{ccccc}
\hline $\begin{array}{c}\text { Kelompok } \\
\text { rumput laut } \\
\text { Seaweed group }\end{array}$ & $\begin{array}{c}\text { Jenis rumput laut } \\
\text { Seaweed species }\end{array}$ & $\begin{array}{c}\text { Kandungan C } \\
\text { C content } \\
\mathbf{( \% )}\end{array}$ & $\begin{array}{c}\text { Tutupan } \\
\text { Coverage } \\
\mathbf{( \% )}\end{array}$ & $\begin{array}{c}\text { Area tutupan } \\
\text { Coverage area } \\
\text { (ha) }\end{array}$ \\
\hline Chlorophyta & Caulerpa sp. & 25.66 & 2.11 & 3.65 \\
Green algae & Halimeda sp. & 9.82 & 9.61 & 16.63 \\
& Halimeda micronesica & 4.53 & 3.29 & 5.69 \\
Bornetella nitida & 9.07 & 0.53 & 0.92 \\
\hline Brown algae & Turbinaria sp. & 22.04 & 1.32 & 2.28 \\
& Padina sp. & 14.18 & 23.68 & 40.97 \\
& Dictyota dichotoma & 18.69 & 5.79 & 10.02 \\
Sargassum sp. & 16.41 & 2.89 & 5.00 \\
Rhodophyta & Hydroclathrus clatratus & 11.78 & 9.34 & 16.16 \\
\hline & Eucheuma spinosum & 16.47 & 3.95 & 6.83 \\
& Gelidium sp. & 16.41 & 0.13 & 0.22 \\
& Gracilaria sp. & 19.59 & 0.13 & 0.22 \\
\hline
\end{tabular}




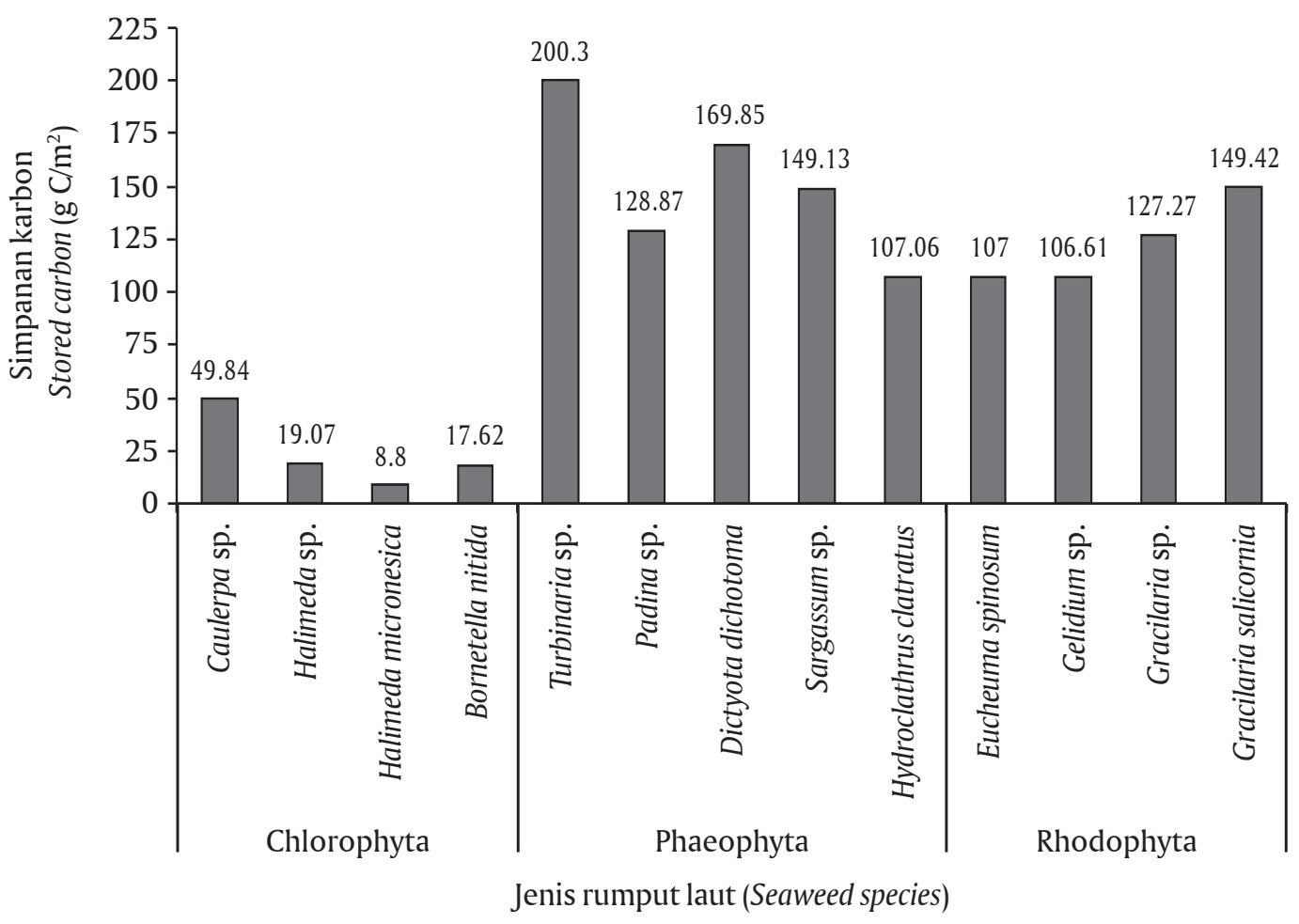

Gambar 6. Variasi simpanan karbon beberapa jenis rumput laut alam di kawasan rataan terumbu Labuhanbua, Kabupaten Sumbawa, Nusa Tenggara Barat

Figure 6. Variability of stored carbon from several wild seaweed species along reef flat area at Labuhanbua, Sumbawa Regency, West Nusa Tenggara

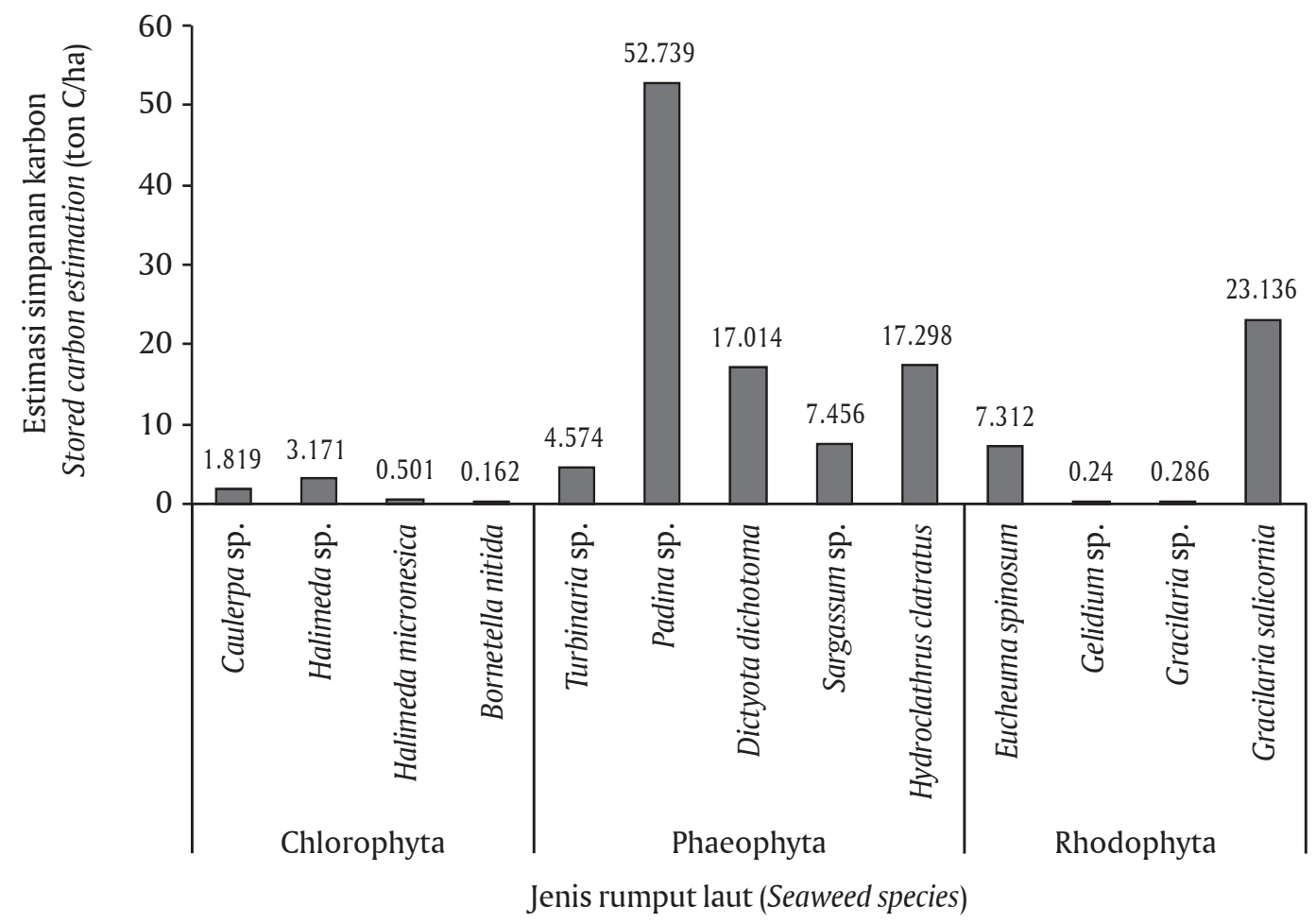

Gambar 7. Estimasi simpanan karbon beberapa jenis rumput laut alam berdasarkan luas tutupan di kawasan rataan terumbu Labuhanbua, Kabupaten Sumbawa, Nusa Tenggara Barat

Figure 7. Stored carbon estimation by several wild seaweed species based on its coverage along reef flat area at Labuhanbua, Sumbawa Regency, West Nusa Tenggara 
dichotoma, Sargassum sp., Hydroclathrus clatratus, Gracilaria sp., dan G. salicornia merupakan spesies rumput laut alam yang sangat potensial dalam konteks karbon biru (blue carbon) di perairan Labuhanbua, Kabupaten Sumbawa.

\section{Potensi Pengembangan Budidaya Jenis Rumput} Laut Alam Berdasarkan Tingkat Serapan Karbon

Saat ini, pemanfaatan rumput laut alam oleh masyarakat di sekitar pantai Ujung Genteng masih relatif sedikit. Potensi perairan pantai ini lebih banyak dimanfaatkan oleh masyarakat untuk aktivitas wisata pantai dan penangkapan ikan. Sebaliknya, rumput laut alam, khususnya jenis Sargassum sp. telah dimanfaatkan oleh masyarakat di sekitar Labuhanbua, Sumbawa dengan cara dipanen pada musim-musim tertentu dan dijual kepada pengumpul lokal. Rumput laut merupakan satu komoditas yang menjadi perhatian sehubungan dengan konteks blue carbon. Hasil identifikasi jenis dan kelimpahan rumput laut alam di Ujung Genteng, Kabupaten Sukabumi dan Labuhanbua, Kabupaten Sumbawa telah mengindikasikan peran penting rumput laut alam tersebut dalam menyerap dan menyimpan karbon dalam bentuk biomassa. Peran penting rumput laut sebagai penyerap karbon (carbon sequester), menjadikan komoditas ini sangat prospektif untuk dikembangkan melalui budidaya.

Di antara spesies rumput laut alam yang ditemukan di perairan Labuhanbua, Kabupaten Sumbawa, dan Ujung Genteng, Kabupaten Sukabumi; terdapat beberapa spesies yang saat ini telah umum diperdagangkan karena memiliki nilai ekonomis yang cukup tinggi. Di antara spesies-spesies komersil tersebut terdapat beberapa jenis yang mempunyai nilai simpanan karbon yang relatif tinggi yaitu Sargassum sp. (149,13-275,20 g C/m²); Gelidium sp. (106,61 g C/m²); Gracilaria sp. (127,27 g C/m²); G. foliifera $(123,70 \mathrm{~g} \mathrm{C} /$ $\left.\mathrm{m}^{2}\right)$; dan G. salicornia $\left(149,42 \mathrm{~g} \mathrm{C} / \mathrm{m}^{2}\right)($ Gambar 4 dan 6). Melihat potensi tersebut, maka konservasi kawasan rumput laut alam yang bernilai ekonomis penting menjadi sangat relevan dengan langkah mitigasi perubahan iklim melalui penyerapan karbon. Besarnya potensi penyerapan karbon oleh berbagai spesies rumput laut yang hanya menempati sebagian kecil dari total luasan perairan laut dapat ditingkatkan dengan cara membudidayakan jenis-jenis potensial tersebut di perairan pantai (Orr, 2014). Usaha budidaya rumput laut selain dapat dijadikan sumber mata pencaharian masyarakat pesisir, secara tidak langsung juga dapat menjadi salah satu langkah dalam mencegah eksploitasi berlebih terhadap rumput laut alam. Selain itu, budidaya rumput laut secara simultan juga berperan dalam mitigasi perubahan iklim melalui penyerapan karbon dari lingkungan. Komoditas ini selain berperan dalam peningkatan perekonomian masyarakat pesisir, juga dapat berkontribusi terhadap lingkungan sebagai penyerap karbon dalam mitigasi perubahan iklim global (Erlania et al., 2013b).

Jenis-jenis rumput laut alam yang memiliki kemampuan menyerap karbon yang tinggi mengindikasikan performa pertumbuhan dan produktivitas yang juga relatif tinggi (Erlania et al., 2013a; Erlania \& Radiarta, 2014). Dalam perspektif pengembangan budidaya rumput laut terkait tujuan utama dari aktivitas budidaya, yaitu produksi biomassa yang optimal, jenis-jenis rumput laut yang memiliki kemampuan tinggi dalam menyerap dan menyimpan karbon tersebut dapat dijadikan sebagai kandidat komoditas budidaya yang potensial. Untuk mendukung diversifikasi komoditas dan peningkatan produksi budidaya rumput laut, perlu dilakukan studi lebih lanjut terkait kandungan bahan aktif/komponen esensial dari jenis-jenis rumput laut alam potensial ini sehingga dapat menghasilkan nilai ekonomis yang tinggi; untuk selanjutnya dapat dilakukan pengembangan teknik budidaya yang sesuai, serta kajian kesesuaian lahan untuk budidaya berdasarkan karakteristik habitat alami dari jenis-jenis rumput laut tersebut. Berkembangnya teknologi budidaya untuk jenis-jenis rumput laut alam tersebut diharapkan dapat meningkatkan produksi budidaya secara global dan memberikan nilai tambah bagi perekonomian masyarakat pesisir, serta memberikan kontribusi yang lebih besar dalam mitigasi perubahan iklim melalui penyerapan karbon.

Menurut Orr (2014), untuk membatasi peningkatan suhu global hingga $2^{\circ} \mathrm{C}$, maka $\sim 3,2 \times 10^{15} \mathrm{gC}$ harus dihilangkan dari atmosfer; dan $10 \%$ dari tujuan ini dapat dicapai melalui budidaya rumput laut pada $4 \%$ dari total luasan perairan zona ekonomi ekslusif (ZEE) untuk 100 tahun ke depan.

\section{KESIMPULAN}

Rumput laut mempunyai peran penting dalam menyerap dan menyimpan karbon dalam bentuk biomassa, baik rumput laut budidaya maupun rumput laut alam. Kapasitas penyerapan dan penyimpanan karbon sangat bergantung dari jenis, lokasi, dan kondisi lingkungan secara global. Kajian yang dilakukan pada dua lokasi berbeda yaitu Ujung Genteng dan Labuhanbua menunjukkan bahwa sumberdaya rumput laut alam yang ada sangat bervariasi, yaitu 36 spesies di kawasan pantai Ujung Genteng dan 28 spesies di Labuhanbua. Berdasarkan kapasitas penyimpanan karbon maka jenis-jenis seperti: Sargassum sp., Padina sp., Dictyota dichotoma, Hydroclathrus clatratus, Gracilaria sp., G. foliifera, G. salicornia, Gelidium sp., dan Turbinaria sp., merupakan jenis-jenis yang memi- 
liki tingkat serapan karbon yang tinggi, dan sangat potensial untuk dikembangkan melalui kegiatan budidaya. Dalam perspektif mitigasi perubahan iklim, langkah strategis yang perlu dilakukan terkait pengembangan budidaya dari jenis-jenis rumput laut potensial tersebut di antaranya adalah studi lebih lanjut terhadap bahan/komponen esensial rumput laut yang bernilai ekonomis, pengembangan teknik budidaya yang sesuai, serta kajian kesesuaian lahan untuk budidaya berdasarkan karakteristik habitat alami dari jenis-jenis rumput laut tersebut.

\section{UCAPAN TERIMA KASIH}

Penulis mengucapkan terima kasih kepada Dinas Kelautan dan Perikanan Kabupaten Sumbawa, NTB dan pengurus klinik bisnis Desa Ujung Genteng, Sukabumi atas bantuannya selama kegiatan lapangan. Penelitian ini dibiayai dari anggaran DIPA Pusat Penelitian dan Pengembangan Perikanan Budidaya tahun 2014.

\section{DAFTAR ACUAN}

Alonso, I., Weston, K., Gregg, R., \& Morecroft, M. (2012). Carbon storage by habitat: Review of the evidence of the impacts of management decisions and condition of carbon stores and sources. Natural England Research Reports, Number NERR0 43, $45 \mathrm{pp}$.

Dawes, CJ. (1981). Marine Botany. John Wiley and Sons, Inc. Canada, 628 pp.

Dadolahi-Sohrab, A., Garavand-Karimi, M., Riahi, H., \& Pashazanoosi, H. (2012). Seasonal variations in biomass and species composition of seaweeds along the northen coasts of Persian Gulf (Bushehr Province). J. Earth Syst. Sci., 121, 241-250.

Elangbam, G., Mayanglambam, A., \& Sahoo, D. (2014). Histochemical study on the impact of high carbon dioxide on Kappaphycus alvarezii. Asia Pacific Journal of Research, I(XIV), 43-51.

Erlania, Nirmala, K., \& Soelistyowati, D.T. (2013a). Penyerapan karbon pada budidaya rumput laut Kappaphycus alvarezii dan Gracilaria gigas di perairan Teluk Gerupuk, Lombok Tengah, Nusa Tenggara Barat. J. Ris. Akuakultur, 8(2), 287-297.

Erlania, Radiarta, I N., \& Sugama, K. (2013b). Peran budidaya rumput laut terhadap penyerapan karbon dan mitigasi perubahan iklim. Analisa Kebijakan Pembangunan Perikanan Budidaya 2013, Puslitbang Perikanan Budidaya, Badan Litbang Kelautan dan Perikanan, Kementerian Kelautan dan Perikanan, hlm. 11-20.

Erlania \& Radiarta, I N. (2014). Perbedaan siklus tanam budidaya rumput laut, Kappaphycus alvarezii, terhadap variabilitas tingkat serapan karbon. J. Ris.
Akuakultur, 9(1), 111-124.

Food and Agriculture Organization [FAO]. (2012). The state of world fisheries and aquaculture. FAO Fisheries and Aquaculture Department-United Nation. Rome, 209 pp.

Grimsditch, G., \& Chung, I.K. (2012). Yeosu Workshop on "Coastal Blue Carbon," PICES Press, 20(2), 18-20.

Kadi, A. (2004). Potensi rumput laut di beberapa perairan pantai Indonesia. Oseana, XXIX(4), 25-36.

Kaladharan, P., Veena, S., \& Vivekanandan, E. (2009). Carbon sequestration by a few marine algae: Observation and projection. Journal of the Marine Biological Association of India, 51(1), 107-110.

Kalsum, S.J. (2012). Jenis-jenis rumput laut. Seaplant.net. $100 \mathrm{hlm}$.

Kementerian Kelautan dan Perikanan [KKP]. (2011). Kelautan dan perikanan dalam angka 2011. $120 \mathrm{hlm}$.

Mitra, A., Zaman, S., Pramanick, P., Bhattacharyya, S.B., \& Raha, A.K. (2014). Stored carbon in dominant seaweeds of Indian Sundarbands. Pertanika Journal Tropical Agricultural Science, 37(2), 263-274.

Muhammading, Suharmaji, Primaputra, P., Khaeruddin, Julmansyah, Nusantara, A., Indrajaya, W., Kurniawati, E., Effendi, M., Ashar, L.M., Sudirman, \& Zaputra, N. (2011). Sumber daya alam spasial Kabupaten Sumbawa tahun 2011. Bappeda Kabupaten Sumbawa, $74 \mathrm{hlm}$.

Muraoka, D. (2004). Seaweed resources as a source of carbon fixation. Bul. Fish. Res. Agen., Supplement, (1), 59-63.

Orr, K.K. (2014). Floating seaweed (Sargassum). In Laffoley, D., Baxter, J., Thevenon, F., \& Oliver, J. (Eds.), The Significance and Management of Natural Carbon Stores in the Open Ocean. Full report. Gland, Switzerland: IUCN, p. 55-67.

Sahayaraj, K., Rajesh, A., Asha, A., Rathi, J.M., \& Raja, P. (2014). Distribution and diversity assessment of the marine macroalgae at four southern districts of Tamil Nadu, India. Indian Journal of GeoMarine Sciences, 43(4), 607-617.

Schumacher, B.A. (2002). Methods for the determination of total organiccarbon (TOC) in soils and sediments. U.S. Environmental Protection Agency, 1282:001. 23 pp.

Smith, C.M. (1992). Diversity in intertidal habitat: An assesment of the marine algae of select high island in the Hawaiian Archipelago. Pacific Science, 46(4), 466-479.

Soekendarsi, E., Juariah, U., Soewardi, K., \& Setyobudiandi, I. (2004). Jenis-jenis rumput laut di Perairan Indonesia. FPIK-IPB. Bogor, $63 \mathrm{hlm}$.

Sukiman. (2011). Biodiversitas dan potensi ganggang merah (Rhodophyta) di perairan Pantai Jawa Barat. 
Sekolah Pascasarjana, Institut Pertanian Bogor. Bogor, $122 \mathrm{hlm}$.

Wahyudi, Y. (2011). Karakteristik sumberdaya pesisir dan laut kawasan Teluk Pelabuhan Ratu,
Kabupaten Sukabumi, Jawa Barat. Bonorowo Wetlands, 1(1), 19-32. 